\title{
An Analysis of Export Led Growth Hypothesis: Cointegration and Causality Evidence from Sri Lanka
}

\author{
Muhammad Tahir ${ }^{1}$, Humayun Khan ${ }^{2, *}$, Muhammad Israr ${ }^{3}$, Abdul Qahar $^{4}$ \\ ${ }^{1}$ Department of Economic, Preston University, Islamabad \\ ${ }^{2}$ Institute of Development Studies, The University of Agriculture-Peshawar, Khyber Pakhtunkhwa-Pakistan \\ ${ }^{3}$ Department of Rural Development, Amir Muhammad Khan Campus-Mardan, The University of Agriculture-Peshawar, Khyber \\ Pakhtunkhwa-Pakistan \\ ${ }^{4}$ Amir Muhammad Khan Campus-Mardan, The University of Agriculture-Peshawar, Khyber Pakhtunkhwa-Pakistan
}

Copyright $@ 2015$ Horizon Research Publishing All rights reserved.

\begin{abstract}
This study examines the export led growth (ELG) hypothesis for Sri Lanka on the basis of annual data for the period 1981 to 2012, drawn from the World Bank (WDI) data bank. The period is selected on the grounds that during the period the Sri Lankan economy has been liberalized and in a liberalized economy it is expected that the trade sector plays a key role in national income determination. The hypothesis is tested with simple GDP and GDP net of exports as proposed by Sharma and Panagiotidis (2005). Johansen cointegration (1988) test is used to check the long run association which rejected the hypothesis of any long run association between export and GDP and GDP net of exports. Same results are also revealed by Granger causality (1969) and existence of short run relationship between exports and GDP and GDP net of exports is also rejected by VAR. However, Granger cause between imports and investment is noticed which run from imports to investment and from investment to imports respectively at $5 \%$ and $10 \%$ level of significance. Unidirectional causality is also recorded, at $05 \%$ level of significance, between investment and unemployment which run from investment to unemployment. However, no empirical evidence in support of ELG hypothesis for Sri Lanka is found.
\end{abstract}

Keywords Export Led Growth, Cointegration and Causality, Sri Lanka

\section{Introduction}

Economic growth is the corner stone of all economic policies and export is considered the engine of economic growth since revelation of the theory of comparative advantage. The neo-classical export led growth (ELG) hypothesis premise that export promotes economies of scale, technological progress, production of higher quality goods and services eliminate unemployment of labor and other factors of production and reduce economic inefficiencies and thus promote economic growth (Helpman and Krugman 1985; Kruger 1985, Rodrik 1988 and Voivodas 1973). This thinking has arisen from the observation that exports create income and employment for the domestic factors of production and is based on the macro-economic argument that exports are injunction into the circular flow of income.

Another school of thought, majorly led by Kaldor (1967), rejects the export led growth hypothesis and views the reverse causation i.e. economic growth promotes exports. This school of thought presumes that economic growth in a country is the result of economies of scale which is the result of innovation, technological advancement and mass scale production (Ghartey, 1993 etc). They view export is just surplus production which is sold in the foreign market.

A third row of economists believe that the relation between economic growth and exports are bi-directional (Helpman and Krugman 1985; Ghartey 1993 and Kunst and Marin 1989 etc). This school of thought believe that trade openness is the best option for the promotion of economic goals like growth and prosperity and elimination of economic inefficiency all over the world. They subscribe to the bi-directional relation between exports and growth.

Still another group of economists completely reject the existence of any long run dynamic relation between economic growth and exports (Pack 1998; 92; and Yaghamian 1994). They believe that both economic growth and trade are the results of the process of structural changes and economic development majorly due to globalization.

Subscribing to a proper scheme of thought on export led growth hypothesis has policy implications. As the ELG hypothesis propagators recommend protection and promotion of exports and import substitution sectors/industries, whereas, trade openness is propagated by the other school of thought who believe in globalized prosperity.

The trend of empirical analysis of export led growth hypotheses can be traced back into the 1970's. In the early studies Spearman rank correlation technique has been used in order to examine the ELG hypothesis (e.g. Kravis 1970; Michaley 1977; Bhagwati 1978 etc). With development of econometric techniques the production function technique with OLS regression analysis is also used (e.g. Balassa 1978, 1985; Feder 1982; Tyler 1981; Ram 1987 and Fosu 1990 etc). 
These studies have verified the existence of strong evidence in support of export led growth hypothesis. However, results of these studies were questioned majorly on the grounds of non-stationarity of data. The development of cointegration and especially Granger (1969) causality technique, Johansen (1988) test for cointegration spurred the fashion of testing the export led growth and related hypothesis with stationary data.

\section{Review of Literature}

A large literature on empirical investigation on the subject is available with mix results. For this study the following empirical studies have been reviewed.

Ray (2011) examined cointegration between export and GDP of India. He applied cointegration and Granger causality techniques using annual time series data for 1971-72 to 2011. The results revealed existence of short and long run cointegration between GDP growth and exports. The presence of bi-directional causality was also observed between exports and GDP.

Afzal et al (2009) examined the export led growth hypothesis in context of external debt serving for Pakistan on the basis of yearly data of GDP, export and debt serving for the period 1971-72 to 2007-08. The hypothesis was tested with Vector Error Correction Model (VECM) and Augmented Vector Autoregressive (AVAR). Results show that both short and long run steady state relation exist among the variables and that the unidirectional Granger causality exist which run from GDP to export and debt serving to GDP. The results support growth driven export hypothesis.

Jordaan and Eita (2007) examined the existence of causality between export and GDP in Namibia by applying cointegration and Granger causality techniques for the annual time series data for 1970 to 2005 . The results attest prevalence of strong unidirectional causality between GDP and export which run from export to GDP. Hence the study confirmed existence of positive relationship between export and GDP for Namibia.

Sharma and Panagoitidis (2005) analyzed the growth and export cointegration for India on the basis of yearly data for 1971 to 2001 . The data for the study was obtained from the source of Reserve Bank of India. Besides Johansen cointegration and Granger causality analysis Breitung's non-parametric cointegration test are also applied for data analysis. The Johansen test results against existence of cointegration between export and GDP also uphold by the Breitung's test results. The simulation results of any shock in export were insignificant, which also support the argument against ELG hypothesis for India.

Stait (2005) examined the ELG hypothesis for Egypt, using data from 1977 to 2003. Cointegration analysis, Granger causality tests, and unit root tests, coupled with vector-auto regression (VAR) and impulse response function (IRF) analyses techniques are used for analysis of data. The results concluded the non-existence of cointegration between GDP, export and import and existence of Granger cause between export and growth.

Shirazi and Manap (2004) tested export led growth hypothesis for 05 South Asian countries i.e. Pakistan, India, Sri Lanka, Bangladesh and Nepal. The study is based on data for the period 1960 to 2002 and cointegration and multivariate Granger causality techniques were applied to examine the hypothesis. The study observed existence of strong long run relation between exports, imports and real GDP for all the countries except Sri Lanka. They also observed existence of unidirectional causality from export to output for Pakistan, a feedback effect between imports to GDP growth for Pakistan, Bangladesh and Nepal and a unidirectional causality from imports to GDP growth for Sri Lanka but no causality was observed in case of India. They also observed feedback between export and GDP growth for Bangladesh and Nepal. The study concluded that the prevalence of export led growth hypothesis for Pakistan, Bangladesh and Nepal but not for India and Sri Lanka.

Sinha (1999) studied relation between export instability, investment and economic growth in Asian countries. He observed negative relation between export instability and GDP growth for Sri Lanka, Japan, Malaysia and Philippines. Results for Pakistan, Korea (South), Myanmar and Thailand show existence of positive relation between growth and exports whereas for India the results were inconclusive.

In case of Sri Lanka very few studies have been carried out on the topic and in most cases the result were either inconclusive or against the export led growth hypothesis (Jim and Love 2005, Anoma 1996 etc). Sinha (1999) tested the cointegration of export instability, investment and economic growth hypothesis for Asian countries including Sri Lanka and reported negative relation between export instability and GDP growth. Love and Chandra (2004) on the basis of multivariate analysis observed no-causality for Sri Lanka. Similarly Shirazi and Manap (2004) tested export led growth hypothesis for 05 South Asian countries including Sri Lanka and observed existence of strong long run relation between exports, imports and real GDP for all the countries except Sri Lanka. They detected a unidirectional causality from imports to GDP growth for Sri Lanka. The study concluded that the presence of export led growth hypothesis hold for other countries but not for India and Sri Lanka. In a study for 05 South Asian countries Uddin (2004), using multivariate time series framework, observed bi-directional causality between exports and output growth besides others for Sri Lanka; however no long run relationship was established between export and GDP growth.

\section{An Overview of Sri Lanka's Economy}

The country has shifted from the socialist orientation in the late 1970's and since then the successive governments have adopted the policy of privatization and deregulation which has positively affected the economy. However, due to 25 years of civil war the economy has not realized its potential growth and development.

The GDP growth which is exhibited in the figure \# 1 has increased at an accelerated pace since 2002. The exports, imports and investment though increased with a lesser pace but the three variables are moving close to each other which very much exhibit the GDP trend all this show the existence 
of long run relationship among these variables. It therefore provides some evidence in support of export led growth hypothesis in case of Sri Lanka.

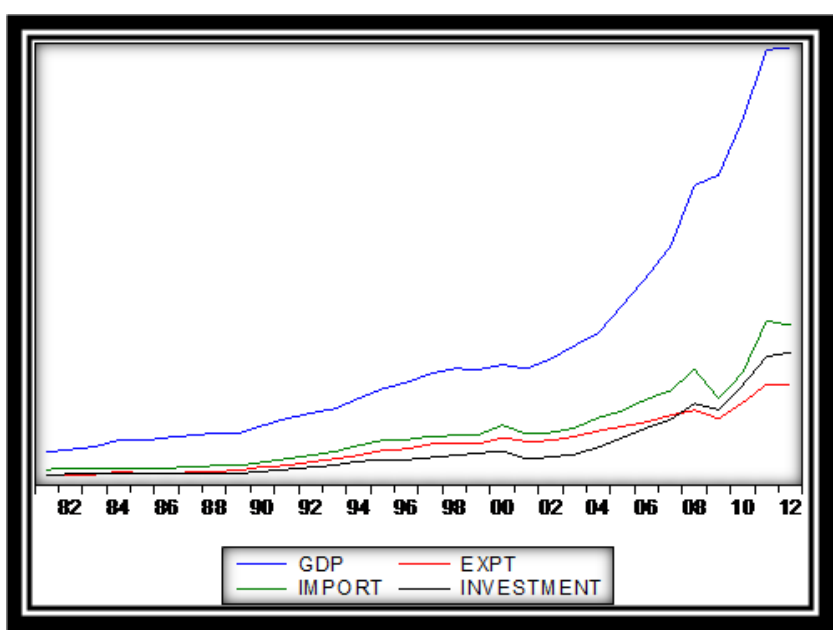

Figure 1. GDP, Exports, Imports and Investment (1981-2012)

However, in most of the studies conducted on the subject conclude rejection of the hypothesis e.g. Jim and Love (2005), Anoma (1996), Sinha (1999) and Uddin (2004) etc. Whereas, in cases of other neighboring countries like Pakistan and Bangladesh the export led growth hypothesis prevail. It may be because of the fact that Sri Lanka was following a pro-socialist policy till the late 1970's which focus on the internal economy and give less weight to the external socio-economic factors. Because of the above we get motivation to test the export led growth hypothesis for Sri Lanka for pro-capitalistic era i.e. 1981 to 2012. Besides that the impact of export is also examined with reference to GDP net of export, imports, investment and unemployment so that there short and long run casual relationship is recognized.

\section{Methodology}

\section{Data}

The study is based on the annual data for the period 1981 to 2012 drawn from the World Bank (World Development Indicators) data bank. Import has been included in the framework of ELG hypothesis on the suggestion of Riezmann et al (1996) who dubbed simple GDP and export framework as biased and argued that foreign trade as a whole has long run causation with the GDP and stressed on the inclusion of import in the ELG model analysis to capture more logical results. Sharma and Panagiotidis (2005) noticed that GDP also include export and in such cases analysis of relation between GDP and export may suffer from accounting bias. In order to get around the problem they propose analysis of GDP_net_of-exports for analyzing ELG hypothesis. Therefore, in this study we included both the GDP and GDP_net_of-exports models for testing the hypothesis.

Data regarding unemployment and investment for the same time period has also been drawn which is used for additional analysis to test their relation with trade variables. For analysis purpose the data has been converted into natural $\log (\ln )$

\section{Analytical Framework}

Due to non-stationarity property of most of the economic time series, OLS results are not valid due to violation of constant mean and variance assumptions. Hence, to investigate the dynamic relationship among the targeted variables Johansen Cointegration Test (1988) is used. For examining direction of relationship between two variables Granger causality (1969) test is used in the VAR system. Vector Auto-Regressive (VAR) system is also used in order to examine the dynamic impact of different of variables with each other.

Detail methodology is discussed below:

\section{Unit Root Test}

In order to check that data stationarity Augmented Dickey-Fuller (ADF)(1979) test is used. This test has the advantage that it uses higher-order autoregressive processes for checking stationarity of data. The test use the following equation

$$
\Delta \mathrm{y}_{\mathrm{t}}=\alpha+\beta \mathrm{t}+\lambda \mathrm{y}_{t-1}+\ldots \ldots \ldots+\delta_{p-1} \Delta \mathrm{y}_{t-p+1}+\varepsilon_{t}
$$

where, $\alpha$ is a constant, $\beta$ the coefficient on a time trend, $\mathrm{p}$ is the lag order of the autoregressive process and $\varepsilon$ is white Gaussian random error term. Imposing the constraints that $\alpha=0$ and $\beta=0$ corresponds to modeling a random walk. Whereas using the constraint that $\beta=0$, corresponds to modeling a random walk with a drift and using the constraint $\alpha=0$, corresponds to modeling a random walk with time trend.

\section{Johansen Cointegration Test}

The existence of long run relationship among the stated time series is tested with Johansen Cointegration (1988) test. The test is selected due to its property that that it can simultaneously test association among more than two variables. In the Johansen framework the following system is estimated

$$
\begin{gathered}
\Delta \mathrm{z}_{\mathrm{t}}=\Gamma_{1} \Delta \mathrm{z}_{\mathrm{t}-1}+\ldots \ldots \ldots+\Gamma_{\mathrm{k}-1} \Delta \mathrm{z}_{\mathrm{t}-\mathrm{k}-1}+\pi \mathrm{z}_{\mathrm{t}-1}+\mu+\varepsilon_{\mathrm{t}} \\
\mathrm{t}=1, \ldots \ldots, \mathrm{T}
\end{gathered}
$$

where $\Delta$ is the first difference operator, $\mathrm{z}=$ vector of variables, $\varepsilon_{t}$ is white-noise error term, $\mu$ is drift variables and $\pi$ is a $(p \times p)$ matrix of the form $\pi=\alpha \beta$, where $\alpha$ and $\beta$ both are $(p \times r)$ matrices of full rank, with $\beta$ containing the $r$ cointegrating relationships and $\alpha$ carrying the corresponding adjustment coefficients in each of the $r$ vectors.

In the Johansen framework two test statistics are used for evaluation of the cointegration i.e. Trace and Eigen-value statistic. The trace statistic for the $\mathrm{H}_{0}$ of $\mathrm{r}$ cointegrating relations is computed as:

$$
\operatorname{Trace}\left(r_{0} / k\right)=-T+>\ln \left(1-\lambda_{i}^{\wedge}\right)
$$

where the $i$ th ordered Eigen-values $[\lambda 1>\lambda 2>\lambda 3 \ldots \ldots>\lambda \mathrm{k}]$ and $\mathrm{r} 0$ ranges from 0 to $\mathrm{k}-1$ depending upon the stage in the sequence. The null hypothesis to test is that $r \leq r 0$ against the alternative hypothesis of $\mathrm{r}>\mathrm{r} 0+1$.

The maximum Eigen-value test is similar to trace statistic however it arises from changing the alternative hypothesis from $\mathrm{r} \geq \mathrm{r} 0+1$ to $\mathrm{r}=\mathrm{r} 0+1$; with the idea to enhance the 
statistical power of the test by limiting the alternative to a cointegration rank which is just one more than $\mathrm{H}_{0}$. The test statistic is as follows:

$$
\lambda_{\max }\left(\mathrm{r}_{0}\right)=-T \ln \left(1-\lambda_{\mathrm{i}}\right) \quad \text { for } \mathrm{i}=\mathrm{r}_{0}+1
$$

\section{Granger Causality Test}

Granger (1980) causality test is used to examine the direction of the relationship between two time series. The test is based on the following Vector Auto-regressive (VAR) system

$$
\begin{aligned}
& \mathrm{y}_{\mathrm{t}}=\mathrm{a}_{1}+\sum_{i=1}^{n} \beta_{i} x_{t-1}+\sum_{i=1}^{n} \gamma_{i} y_{t-1}+\varepsilon_{1 t} \\
& \text { and } \mathrm{x}_{\mathrm{t}}=\mathrm{a}_{2}+\sum_{i=1}^{n} \theta_{i} x_{t-1}+\sum_{i=1}^{n} \delta_{i} y_{t-1}+\varepsilon_{2 t}
\end{aligned}
$$

where, $\varepsilon_{i t}$ are white Gaussian random vector, $\mathrm{x}$ and $\mathrm{y}$ are the variables to be tested. In this VAR if $\log$ of $\mathrm{x}$ term in equation 1 is significant and $\log$ of $y$ in equation 2 is not significant; then there exists a unidirectional causation running from $\mathrm{x}$ to $\mathrm{y}$. The opposite is true when $\mathrm{y}$ is significant in equation 2 with insignificant $\mathrm{x}$ in equation 1 . In case both are significant then there exists a bi-directional causation. However if the two variables in the two equations are insignificant then existence of any causation between the two is rejected.

\section{Results and Discussions}

As already stated in the preceding sections that Johansen cointegration (1988) and Granger causality (1969) can be used only in cases of stationary data $s$ the data has been checked for stationarity by using the Augmented Dickey Fuller (ADF) test. The test results are presented below (table 1).

On the basis of the above results we can see that the data of all the selected variables is non-stationary at level, however, when convert into first difference it becomes stationary. Hence the above series are integrated of order 1 i.e. I(1).

Since the data is non-stationary at level and becomes stationary at first difference so both conditions of Johansen cointegration test are fulfilled so we used the same. The Akaike information criteria is used for selection of model and allowing for liner deterministic trend in data intercept and trend format/specification is used (in Eview this is model \# 4 in the Johansen test models).

Results of the same for both the models are presented in the following tables (Table 2-3)

The above results illustrate non-existence of any long run relationship or cointegration among the three series. Hence does not support the export led growth hypothesis for Sri

\begin{tabular}{|c|c|c|c|c|c|c|}
\hline \multirow[b]{2}{*}{ Series } & \multicolumn{3}{|c|}{ At level } & \multicolumn{3}{|c|}{ At First Difference } \\
\hline & Intercept & $\begin{array}{c}\text { Intercept and } \\
\text { Trend }\end{array}$ & Decision & Intercept & $\begin{array}{c}\text { Intercept and } \\
\text { Trend }\end{array}$ & Decision \\
\hline Ln_GDP & $\begin{array}{l}1.319 \\
(.099)\end{array}$ & $\begin{array}{l}-3.149 \\
(.0115) \\
\end{array}$ & Non-Stationary & $\begin{array}{c}-4.518 \\
(0.0012) \\
\end{array}$ & $\begin{array}{l}-4.744 \\
(.0034) \\
\end{array}$ & Stationary \\
\hline Ln_GDP_Exp & $\begin{array}{l}1.776 \\
(0.99) \\
\end{array}$ & $-0.177(.991)$ & Non-Stationary & $\begin{array}{l}-3.546 \\
(0.013) \\
\end{array}$ & $\begin{array}{l}-3.887 \\
(.025) \\
\end{array}$ & Stationary \\
\hline Ln_Exports & $\begin{array}{l}-0.221 \\
(0.925) \\
\end{array}$ & $\begin{array}{l}-2.209 \\
(0.468) \\
\end{array}$ & Non-Stationary & $\begin{array}{c}-6.28 \\
(0.000) \\
\end{array}$ & $\begin{array}{l}-6.145 \\
(0.000) \\
\end{array}$ & Stationary \\
\hline Ln_Imports & $\begin{array}{c}0.378 \\
(0.978) \\
\end{array}$ & $\begin{array}{l}2.866 \\
(.816) \\
\end{array}$ & Non-Stationary & $\begin{array}{l}-6.316 \\
(0.000)\end{array}$ & $\begin{array}{c}-6.449 \\
(0.000) \\
\end{array}$ & Stationary \\
\hline Ln_Investment & $\begin{array}{c}1.218 \\
(0.998)\end{array}$ & $\begin{array}{l}1.122 \\
(908)\end{array}$ & Non-Stationary & $\begin{array}{l}-4.766 \\
(0.001)\end{array}$ & $\begin{array}{l}-5.284 \\
(0.001)\end{array}$ & Stationary \\
\hline Ln_Unemployment & $\begin{array}{l}1.167 \\
(.997) \\
\end{array}$ & $\begin{array}{l}-1.605 \\
(0.767) \\
\end{array}$ & Non-Stationary & $\begin{array}{l}-5.980 \\
(0.000)\end{array}$ & $\begin{array}{l}-6.656 \\
(0.000) \\
\end{array}$ & Stationary \\
\hline
\end{tabular}
Lanka.

Table 1. Unit Root Analysis (Augmented Dickey-Fuller Test)

Table 2. Johansen Cointegration test Natural Log of (GDP, Exports and Imports)

\begin{tabular}{|c|c|c|c|c|c|c|c|}
\hline $\begin{array}{c}\text { Hypothesized } \\
\text { No. of CE(s) }\end{array}$ & Eigen value & $\begin{array}{c}\text { Trace } \\
\text { Statistic }\end{array}$ & $0.05 \mathrm{CV}$ & Prob.** & $\begin{array}{c}\text { Max-Eigen } \\
\text { Statistic }\end{array}$ & $0.05 \mathrm{CV}$ & Prob.** $^{* *}$ \\
\hline None & 0.572884 & 35.62756 & 42.91525 & 0.2202 & 25.52097 & 25.82321 & 0.0548 \\
\hline At most 1 & 0.209381 & 10.10659 & 25.87211 & 0.9204 & 7.048154 & 19.38704 & 0.8975 \\
\hline At most 2 & 0.096923 & 3.058439 & 12.51798 & 0.8695 & 3.058439 & 12.51798 & 0.8695 \\
\hline
\end{tabular}

Trace and Max-Eigen-value statistics indicates no cointegration at the 0.05 level

Table 3. Johansen Cointegration test Natural Log of (GDP net of exports, Exports and Imports)

\begin{tabular}{|c|c|c|c|c|c|c|c|}
\hline $\begin{array}{c}\text { Hypothesized } \\
\text { No. of CE(s) }\end{array}$ & Eigen value & $\begin{array}{c}\text { Trace } \\
\text { Statistic }\end{array}$ & $\begin{array}{c}\text { Critical Value } \\
0.05\end{array}$ & Prob.** & $\begin{array}{c}\text { Max-Eigen } \\
\text { Statistic }\end{array}$ & $\begin{array}{c}\text { Critical Value } \\
0.05 \text { CV }\end{array}$ & $\begin{array}{c}\text { Prob.** } \\
\text { None }\end{array}$ \\
\hline At most 1 & 0.575104 & 35.96622 & 42.91525 & 0.2075 & 25.67735 & 25.82321 & 0.0523 \\
\hline At most 2 & 0.089779 & 2.822037 & 12.51798 & 0.8970 & 2.822037 & 12.51798 & 0.8970 \\
\hline
\end{tabular}

Trace and Max-Eigen-value statistics indicates no cointegration at the 0.05 level 


\section{Granger Causality Test}

Granger (1969) causality test, in the VAR environment, provides information regarding the direction of relationship between two variables. In this case we examine the export led growth hypothesis for the case of Sri Lanka to see whether exports or imports have any impact on the GDP or not. And if yes what is the direction of relationship i.e. whether export cause GDP growth or it is the other way around.

Granger causality test is very sensitive to the lag selection. Thus in order to select optimal lag for the model we tested the lag selection criteria with Akaik Information Criteria which propose use of Lag-1 model. Results for the $1^{\text {st }}$ difference of the two models i.e. $\log$ of GDP and $\log$ of GDP net of exports for log of exports and $\log$ of imports are presented in the following table.

Table 4. Granger Causality ( $1^{\text {st }}$ Difference log of GDP and Log of Exports)

\begin{tabular}{|c|c|c|c|}
\hline \multicolumn{4}{|c|}{ Pair-wise Granger causality tests } \\
\hline $\begin{array}{c}\text { Sample: 1981-2012 Lag 1 } \\
\text { Null Hypothesis }\end{array}$ & Obs & F-Statistic & Prob. \\
\hline $\begin{array}{c}\text { LN_EXP does not Granger } \\
\text { Cause LN_GDP }\end{array}$ & 30 & 2.0291 & 0.1658 \\
\hline $\begin{array}{c}\text { LN_GDP does not Granger } \\
\text { Cause LN_EXP }\end{array}$ & 30 & 0.4349 & 0.5151 \\
\hline
\end{tabular}

Table 5. Granger Causality ( $1^{\text {st }}$ Difference log of GDP and Log of Imports)

\begin{tabular}{|c|c|c|c|}
\hline \multicolumn{4}{|c|}{ Pair-wise Granger causality tests } \\
\hline $\begin{array}{c}\text { Sample: 1981-2012 Lag 1 } \\
\text { Null Hypothesis }\end{array}$ & Obs & F-Statistic & Prob. \\
\hline $\begin{array}{c}\text { LN_IMP does not Granger Cause } \\
\text { LN_GDP }\end{array}$ & 30 & 1.96058 & 0.1728 \\
\hline $\begin{array}{c}\text { LN_GDP does not Granger } \\
\text { Cause LN_IMP }\end{array}$ & 30 & 0.02193 & 0.8834 \\
\hline
\end{tabular}

Table 6. Granger Causality $\left(1^{\text {st }}\right.$ Difference $\log$ of Exports and Log of Imports)

\begin{tabular}{|c|c|c|c|}
\hline \multicolumn{4}{|c|}{ Pair-wise Granger causality tests } \\
\hline $\begin{array}{c}\text { Sample: 1981-2012 Lag 1 } \\
\text { Null Hypothesis }\end{array}$ & Obs & F-Statistic & Prob. \\
\hline $\begin{array}{c}\text { LN_IMP does not Granger } \\
\text { Cause LN_EXP }\end{array}$ & 30 & 0.5655 & 0.4585 \\
\hline $\begin{array}{c}\text { LN_EXP does not Granger } \\
\text { Cause LN_IMP }\end{array}$ & 30 & 1.7486 & 0.1971 \\
\hline
\end{tabular}

Table 7. Granger Causality ( $1^{\text {st }}$ Difference log of GDP net of Exports and Log of Exports)

\begin{tabular}{|c|c|c|c|}
\hline \multicolumn{4}{|c|}{ Pair-wise Granger causality tests } \\
\hline $\begin{array}{c}\text { Sample: 1981-2012 Lag 1 } \\
\text { Null Hypothesis }\end{array}$ & Obs & F-Statistic & Prob. \\
\hline $\begin{array}{c}\text { LN_EXP does not Granger Cause } \\
\text { LN_GDP net of export }\end{array}$ & 30 & 0.5615 & 0.4601 \\
\hline $\begin{array}{c}\text { LN_GDP net of export does not } \\
\text { Granger Cause LN_EXP }\end{array}$ & 30 & 0.2528 & 0.6192 \\
\hline
\end{tabular}

Table 8. Granger Causality (log of GDP Net of Exports and Log of Imports)

\begin{tabular}{|c|c|c|c|}
\hline \multicolumn{4}{|c|}{ Pair-wise Granger causality tests } \\
\hline $\begin{array}{c}\text { Sample: 1981-2012 Lag 1 } \\
\text { Null Hypothesis }\end{array}$ & Obs & F-Statistic & Prob. \\
\hline $\begin{array}{c}\text { LN_IMP does not Granger } \\
\text { Cause LN_GDP-net of export }\end{array}$ & 30 & 1.5048 & 0.2305 \\
\hline $\begin{array}{c}\text { LN_GDP net of export does } \\
\text { not Granger Cause LN_IMP }\end{array}$ & 30 & 0.0135 & 0.9085 \\
\hline
\end{tabular}

The above results confirm the Johansen cointegration test results and reject the presence of any causal relationship between the variables in question for both models. Hence it provides strong evidence against the export led growth hypothesis in case of Sri Lanka. Our results very much support the results of Jim and Love (2005), Anoma (1996) and Shirazi and Manap (2004).

As we already discussed in the methodology and introduction section that investment can also affect GDP, Unemployment, Exports and Imports (Sharma and Panagiotidis, 2005), so we also examined the effect of investment on other variables. In order to test the role of investment, in case of Sri Lanka, on other variables we analyzed the Granger causality test is applied and results of the model are presented below

Table 9. Granger Causality ( $\left(1^{\text {st }}\right.$ Difference log of Investment and Log of Exports)

\begin{tabular}{|c|c|c|c|}
\hline \multicolumn{4}{|c|}{ Pair-wise Granger causality tests } \\
\hline $\begin{array}{c}\text { Sample: 1981-2012 Lag 1 } \\
\text { Null Hypothesis }\end{array}$ & Obs & F-Statistic & Prob. \\
\hline $\begin{array}{c}\text { LN_Investment does not } \\
\text { Granger Cause LN_Exports }\end{array}$ & 30 & 0.3932 & 0.5359 \\
\hline $\begin{array}{c}\text { LN_Exports does not Granger } \\
\text { Cause LN_Investment }\end{array}$ & 30 & 0.2705 & 0.6042 \\
\hline
\end{tabular}

Table 10. Granger Causality $\left(1^{\text {st }}\right.$ Difference log of Investment and Log of Imports)

\begin{tabular}{|c|c|c|c|}
\hline \multicolumn{4}{|c|}{ Pair-wise Granger causality tests } \\
\hline $\begin{array}{c}\text { Sample: 1981-2012 Lag 1 } \\
\text { Null Hypothesis }\end{array}$ & Obs & F-Statistic & Prob. \\
\hline $\begin{array}{c}\text { LN_Investment does not Granger } \\
\text { Cause LN_Imports }\end{array}$ & 30 & 3.3933 & 0.0765 \\
\hline $\begin{array}{c}\text { LN_Imports does not Granger Cause } \\
\text { LN_Investment }\end{array}$ & 30 & 5.3049 & 0.0292 \\
\hline
\end{tabular}

Table 11. Granger Causality ( $1^{\text {st }}$ Difference log of Investment and Log of Unemployment)

\begin{tabular}{|c|c|c|c|}
\hline \multicolumn{4}{|c|}{ Pair-wise Granger causality tests } \\
\hline $\begin{array}{c}\text { Sample: 1981-2012 Lag 1 } \\
\text { Null Hypothesis }\end{array}$ & Obs & F-Statistic & Prob. \\
\hline $\begin{array}{c}\text { LN_Unemployment does not } \\
\text { Granger Cause LN_investment }\end{array}$ & 30 & 1.0514 & 0.3143 \\
\hline $\begin{array}{c}\text { LN_Investment does not Granger } \\
\text { Cause LN_Unemployment }\end{array}$ & 30 & 4.9043 & 0.0354 \\
\hline
\end{tabular}

These results also show the absence of any Granger cause between investment and export. However investment has Granger cause with imports and unemployment. In case of unemployment Granger cause direction is from investment to unemployment which is significant at 5\% level of significance. The same is very logical as investment increase unemployment decrease and vice versa.

In case of imports the Granger cause runs from imports to investment. Investment impact on imports is rejected at 5\% level of significance; however, the same can't be rejected at $10 \%$ level. Hence there is also evidence, though weak evidence, in support Granger cause, running from investment to imports. Hence we can't reject the existence of bidirectional relation between the two variables at $10 \%$ level of significance. 


\section{Vector Auto-Regressive Analysis (VAR)}

Existence of simultaneity is a common issue in economic models in particular in time series data analysis. In such cases the selection of exogenous and endogenous variables becomes a problem for the researchers. Sim (1980) suppose that in case of existence of simultaneity all the variables should be treated alike or there should be no difference between the endogenous and exogenous variables. Once this distinction is removed then all the variables have to be treated as exogenous variables. The Vector Auto-regressive model provides a tool to get away with this problem. In VAR model all the variables are treated as exogenous and all the variables and its lags are used as endogenous variables in order to examine a dynamic relationship among different variables. An appropriate model from the same is selected on the basis of its econometric features. VAR models in differenced time series provide a good tool for testing the presence of short run relation between/among different variables. Econometric theory presumes that lag selection has reasonable impact on the model analysis in case of VAR and Granger causality hence optimal lag selection criteria on the basis of AIC and SC. Results of the VAR test are appended which presume rejection of any short run relationship between exports and GDP and GDP net of exports for Sri Lanka.

\section{Conclusions}

The Augmented Dicky-Fuller unit root test clarified the non-stationarity of the three series i.e. GDP, Exports and Imports; at level but becomes stationary at the first difference. Therefore, the series are integrated of order one i.e $I(1)$. The Johansen cointegration test was applied for testing cointegration and the test results failed to provide any evidence in support of long run relationship among GDP and GDP net of exports and exports and imports. Both Trace and Max-Eigen Statistic could not reject the null hypothesis of non-existence of long run relationship for the two models. Similarly, Granger causality results also augmented the findings of cointegration test. However, Granger cause was noticed for Import and Investment and Investment and Unemployment which run from imports to investment and investment to unemployment at $05 \%$ level of significance. Weak evidence in support of Granger between investment and import which run from investment to import at $10 \%$ level of significance is also observed. Hence, it is concluded that a weak bidirectional Granger cause exist between imports and investment. Existence of any short run relation among the targeted variables is also rejected by VAR model results. Thus on the whole it is concluded that no short or long run relation exist between the export and GDP growth of Sri Lanka

\section{Appendix}

\begin{tabular}{|c|c|c|c|}
\hline \multicolumn{2}{|c|}{$\begin{array}{l}\text { Vector Autoregression Estimates } \\
\text { Sample (adjusted): } 19842012\end{array}$} & & \\
\hline \multicolumn{4}{|c|}{ Standard errors in ( ) \& t-statistics in [ ] } \\
\hline \multirow{4}{*}{ D(LN_GDP(-1)) } & D(LN_GDP) & D(LN_EXP) & D(LN_IMP) \\
\hline & 0.242288 & -0.475375 & -0.499763 \\
\hline & $(0.33809)$ & $(0.51742)$ & $(0.64883)$ \\
\hline & {$[0.71664]$} & {$[-0.91874]$} & {$[-0.77025]$} \\
\hline \multirow[t]{3}{*}{ D(LN_GDP(-2)) } & 0.362359 & 0.457683 & 0.831442 \\
\hline & $(0.32791)$ & $(0.50184)$ & $(0.62929)$ \\
\hline & {$[1.10506]$} & {$[0.91201]$} & {$[1.32123]$} \\
\hline \multirow[t]{3}{*}{ D(LN_EXP(-1)) } & -0.127230 & -0.041635 & 0.521156 \\
\hline & $(0.20716)$ & $(0.31704)$ & $(0.39756)$ \\
\hline & {$[-0.61417]$} & {$[-0.13132]$} & {$[1.31090]$} \\
\hline \multirow[t]{3}{*}{ D(LN_EXP(-2)) } & -0.126640 & -0.438082 & -0.135097 \\
\hline & $(0.21943)$ & $(0.33582)$ & $(0.42110)$ \\
\hline & {$[-0.57714]$} & {$[-1.30453]$} & {$[-0.32082]$} \\
\hline \multirow[t]{3}{*}{ D(LN_IMP(-1)) } & -0.064173 & 0.051150 & -0.316965 \\
\hline & $(0.16482)$ & $(0.25225)$ & $(0.31631)$ \\
\hline & {$[-0.38935]$} & {$[0.20278]$} & {$[-1.00207]$} \\
\hline \multirow[t]{3}{*}{ D(LN_IMP(-2)) } & -0.068623 & 0.058820 & -0.413443 \\
\hline & $(0.16056)$ & $(0.24572)$ & $(0.30812)$ \\
\hline & {$[-0.42741]$} & {$[0.23938]$} & {$[-1.34181]$} \\
\hline \multirow[t]{3}{*}{$\mathrm{C}$} & 0.062344 & 0.109341 & 0.075484 \\
\hline & $(0.02672)$ & $(0.04090)$ & $(0.05128)$ \\
\hline & [ 2.33306] & {$[2.67366]$} & [ 1.47193$]$ \\
\hline
\end{tabular}




\begin{tabular}{cccc}
\hline \hline R-squared & 0.159773 & 0.132972 & 0.196281 \\
Adj. R-squared & 0.069380 & 0.103490 & 0.022915 \\
Sum sq. resids & 0.097721 & 0.228883 & 0.359905 \\
S.E. equation & 0.066647 & 0.101999 & 0.127904 \\
F-statistic & 0.697232 & 0.562340 & 0.895457 \\
Log likelihood & 41.39829 & 29.05744 & 22.49432 \\
Akaike AIC & -2.372296 & -1.521203 & -1.068574 \\
Schwarz SC & -2.042259 & -1.191166 & -0.738537 \\
Mean dependent & 0.084138 & 0.079310 & 0.080000 \\
S.D. dependent & 0.064449 & 0.097098 & 0.126463 \\
\hline Determinant resid covariance (dof adj.) & $1.42 \mathrm{E}-07$ & \\
Determinant resid covariance & $6.19 \mathrm{E}-08$ & \\
Log likelihood & 117.2186 & \\
Akaike information criterion & -6.635764 & \\
Schwarz criterion & -5.645653 & \\
\hline \hline
\end{tabular}

foreign trade. MIT-Press.

\section{REFERENCES}

[1] Afzal, M., H. ur-Reman, and J. ur-Rehman (2009). Causal nexus between economic growth, export and external debt serving; the case of Pakistan. Paper presented in the 24 Annual General Meeting and Conference of PSDE Economic Sustainability in a Globalised World.

[2] Anoma S. P. A. (1996). Foreign trade and economic growth evidence from Sri Lanka, 1960-1992. Applied Economics Letters Volume 3, Issue 9, 1996.

[3] Balassa, B. (1978). Export and economic growth: further evidence. Journal of development economics 5, no 2:181-89.

[4] --------- (1985). Exports, policy choices and economic growth in developing countries after the 1973 oil shock. Journal of development economics 18. No.1:23-35.

[5] Export and economic growth: further evidence. Journal of development economics 5, no 2:181-89.

[6] Bhagwati, J.N (1978). Anatomy and consequences of exchange control regimes. Ballinger Publishing, New York.

[7] Dickey, D.A and W.A. Fuller (1979), Distribution of estimators of autoregressive time series with a Unit Root. Journal of the American Statistical Association, no.7:,427-31.

[8] Feder, G. (1982). On export and economic growth. Journal of Development Economics 12. No.1-2:59-73.

[9] Fosu, A. Kwasi (1990). Exports and economic growth: the African case. World Development 18, No. 6:831-35.

[10] Granger, Clive W. J., (1969). Investigating causal relationship by econometric models and cross spectral methods. Econometrica no. 37: 424-38.

[11] Ghartey, E. (1993). Causal relationship between exports and economic growth: some empirical evidence in Taiwan, Japan and the US. Applied economics25: 1145-52.

[12] Helpman, E. and P. Krugman (1985). Market structure and
[13] Johansen, S. (1988). Statistical analysis of cointegration vectors. Journal of Economic Dynamics and Control, Vol. 12: 231-254.

[14] Jordaan, A. C. and J. H. Eita (2007). Export and economic growth in Namibia: A Granger causality analysis". South African Journal of Economics, Vol 75:3.

[15] Kaldor, N. (1967). Strategic factors in economic development New York: Ithaca.

[16] Kravis, Irving B. (1970). Trade as handmaiden of growth: similarities between the nineteenth and twentieth centuries. Economic Journal 80, no. 320: 850-870.

[17] Krueger, A. O. (1985). The experience and lessons of Asia's super exporters, in V. Corbo, A.Krueger, and F. Ossa (eds) export-oriented development strategies: the success of five newly industrializing countries. West View Press, Boulder, Co.

[18] Kunst, R.M. and Marin, D. (1989). On exports and productivity: a causal analysis. Review of Economics and Statistics, 71, 695-703.

[19] Love, J. and R. Chandra, (2005). Testing export-led growth in South Asia". Journal of Economic Studies, V. 32.No: 2:132145.

[20] Love, J. and R. Chandra, (2004). Testing export-led growth in India, Pakistan and Sri Lanka using a multivariate framework. The Manchester school 72:483-496.

[21] Michealy, M. (1977). Exports and growth: an empirical investigation. Journal of Development Economics 4: 49-53.

[22] Pack, H. (1992). Learning and productivity changes in developing countries in G.K. Helleiner (ed.) Trade policy, Industrialization, and Development, Clarendon Press, Oxford.

[23] Ram, R. (1987). Exports and economic growth in developing countries: evidence from time series and cross section data. Economic development and cultural change 36, no. 1:51-72.

[24] Riezman, R. Whiteman, C.H. and Summers, P.M. (1996). The engine of growth or its handmaiden? A time series assessment 
of export led growth. Empirical economics 21, no 1:77-110.

[25] Rodrik, D. (1988). Closing the technology gap: does trade liberalization really help? Cambridge NBER working paper no. 2654 .

[26] Ray S. (2011). A causality analysis on the empirical nexus between export and economic growth: evidence from India". Journal of International affairs and global strategy, Vol I (ISSN 2224-8951 (online)).

[27] Sinha, D. (1999). Export instability, investment and economic growth in Asian countries: A time series analysis. Economic Growth Centre of Yale University Discussion Paper No. 799.

[28] Sharma and Panagoitidis (2005), An analysis of export and growth in India: Cointegration and causality evidence (1971-2001). Review of Development Economics, 9(2), 232-248.

[29] Shirazi, N. S. and T.A.A. Manap (2004). Export led growth hypothesis: further Econometric evidence from Pakistan Pakistan Development Review, Vol. 43: p 472-88.

[30] Sims, Christopher A. 1980. Macroeconomics and Reality.
Econometrica. 48:1-48.

[31] Stait F. A. (2005). Are export the engine of economic growth? An application of cointegration and causality analysis for Egypt (1977-2003). African Development Bank Economic Research Working Paper No 76.

[32] Tyler W.G. (1981) Growth and export expansion in developing countries: some empirical evidence, Journal of Development Economics, 9, 121-30

[33] Uddin (2004), Exports, Imports, and Economic Growth in South Asia: Evidence Using a Multivariate Time-series Framework. The Pakistan Development Review 43(2):pp.105-124.

[34] Voivodas, C. (1973). Exports, foreign capital inflows and economic growth. Journal of International Economics, 3, $337-49$.

[35] Yaghmaian, B. (1994). An empirical investigation of exports, development and growth in developing countries: challenging the neo-classical theory of export-led growth. World Development, no. 22, 1977-95. 